\title{
ASSESSMENT OF SUSTAINABILITY OF AFFORDABLE HOUSING IN MALAYSIA
}

\author{
N. Rizal ${ }^{1 *}$, Z. Tarmidi $^{1}$, N. Razali ${ }^{2}$, S. Pisol $^{3}$ \\ ${ }^{1}$ Geoinformation, Faculty of Built Environment and Survey, Universiti Teknologi Malaysia, 81310 UTM \\ Johor Bahru, Johor - nurfarhanirizal95@gmail.com, zakritarmidi@utm.my \\ ${ }^{2}$ Real Estate, Faculty of Built Environment and Survey, Universiti Teknologi Malaysia, 81310 UTM \\ Johor Bahru, Johor - mnajibmr@utm.my \\ ${ }^{3}$ Map2u Sdn Bhd, 71800 Nilai, Negeri Sembilan - msufipisol@gmail.com
}

KEY WORDS: Affordable housing, sustainable housing, GIS analysis, sustainability level, sustainability indicators, spatial framework.

\begin{abstract}
:
Housing is a basic need that can enhance the quality of life. The government is committed towards ensuring access to quality and affordable housing to meet the needs of a growing population by matching demand and supply, promoting an efficient and sustainable housing industry, as well as providing efficient public utilities and services and a clean environment. Thus, it is imperative for the government and private sector, to work together in order to create a competitive and sustainable housing industry. One of the aspect need improve is the sustainability level of this affordable housing. The aim of this study is to enhance the model to measure the sustainability level of the affordable housing in Malaysia using spatial analysis. The spatial analysis used in this study are both GIS analysis and non-GIS analysis. The result of this study will be list of indicators to measure the sustainability level of affordable housing, and then, from the analysis, map of the sustainability indicators nearby the affordable housing can be produced.
\end{abstract}

\section{INTRODUCTION}

Housing is a basic need that can enhance the quality of life. The government is committed towards ensuring access to quality and affordable housing to meet the needs of a growing population by matching demand and supply, promoting an efficient and sustainable housing industry, as well as providing efficient public utilities and services and a clean environment (KPKT, 2011).

In this regard, the formulation of the National Housing Policy (NHP) is timely to assist the private sector to respond to the government's aspiration towards providing adequate and affordable houses for the lower income group. However, most of the affordable housing did not meet the criteria of the sustainability housing industry and unbalanced social needs, economy and the surrounding environment (Jamilah Mohamad, 2014). Aside from quality construction materials, sustainable housing also requires an access for the housing facilities which promotes the social unity and the serenity (Goh Hong Ching, 2014).

Affordable housing can reduce the cost of living in urban areas, with lower rental and purchase rates. In addition, to improve the quality of life in the city, one of the key components of housing is the sustainability and balanced living style among social, economic and environmental needs (Bakar and Jusoh, 2017).

In Malaysia, the concept of sustainable housing is still new to the public (Hassan, Khor and Rahmawaty, 2011). Jason (as quoted in Hassan et al.) highlighted three main problems that exist in houses built in the past decade. First, energy efficiency and green affordable housing did not take building design into account. Second, sustainability of housing development mostly focuses on environmental, economic and social issues.
Third, covers groups of buildings in the housing development affect environmental performance. According to Hassan, Khor, and Rahmawaty (2011), sustainable housing development should use sustainability criteria to measure developed area, especially in terms of environmental, social, economics, site/ land uses, transportation and communication. It should also include the building assessment forms for the purpose of assessing housing performance.

Besides criteria from NHP and MURNInets, one of the indicators that can be used to measure the sustainability of housing is the Malaysian Family Welfare Index (IKKM) developed by LPPKN. The KLCI aims to measure the level of family well-being through the household's assessment of the parents of the well-being of their families (LPPKN, 2016). The index has 7 domains with 23 indicators in 2011, and has been added to eight domains in 2016, with 23 indicators. This indicator is a Family Relationship Domain, Family Economic Domain, Family Health Domain, Family Safety Domain, Family Domain and Community Involvement, Family Doman, Religious Role and Spiritual Practice, Housing and Family Domain and Family Domain and Communication Technology (LPPKN , 2016).

In this case study, there will be few indicators to identify the sustainability of the affordable housing. The indicators will show the geospatial information about the affordable housing area. The geospatial information will be used for the mapping of the sustainability of the affordable housing. The information then could help certain authorities to execute an efficient planning or strategy to increase the sustainability of the affordable housing area.

\footnotetext{
* Corresponding author
} 


\section{METHODOLOGY}

Study approach is carried out to outline the workflow of this study.

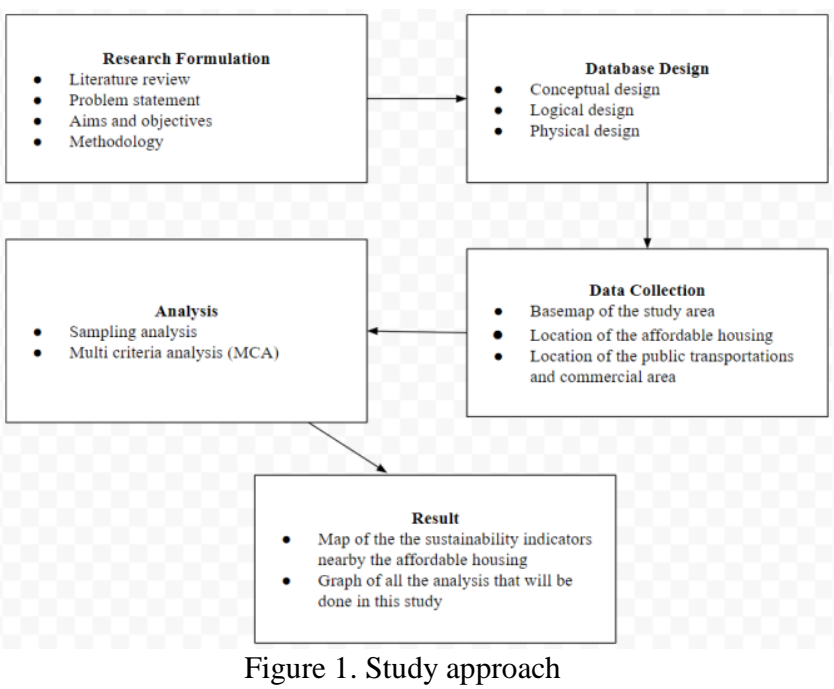

There are several steps that are needed to accomplish this study such as research formulation, database design, data collection, analysis and finally the output of this study. Each phase is shown in figure 1.

Research formulation consists of problem statement, aims, objectives, methodology and literature review. This stage is the initial step in this study. In order to obtain accurate information, sources like journal, articles, thesis and other reliable contents are used in this study. The problem statement of this research is there is no suitable spatial measurement as indicators of the affordable housing area. Aims and objectives of this study are to enhance the spatial framework to measure the sustainability level of the affordable housing in Malaysia and to identify the issues and the factors of spatial indicators for measuring sustainability level of the affordable housing. Methodology of the study are sampling analysis and Multi Criteria Analysis (MCA). Literature review is the stage where the details information about affordable and sustainable housing.

Database is a crucial component in a workflow. The main purpose of database development is to store the data. Database design is important to define the required data structures, types and number of entities, and also the physical size of the database. There are three type of database which are: conceptual design, logical design and physical design. In this study, the conceptual model contains several entities such as the landuse of the study area, residential lot and roads.

Conceptual design is the first step of designing a database. The design is represented by using Entity-Relationship(ER) Diagram. ER Diagram describes the relationship of the entities with one another and also explains the attributes of each entities. ER Diagram contains several components such as entities, relationship and the connection line. In this study, the conceptual model contains several entities such as the landuse of the study area, residential lot and roads.

Based on the conceptual design of this research, the residential is nearby the entities bus stop and railway station. Their attributes are the ID and Name. The entities are inside the entities city center, commercial area and district. All the entities have road with attributes ID and Name.

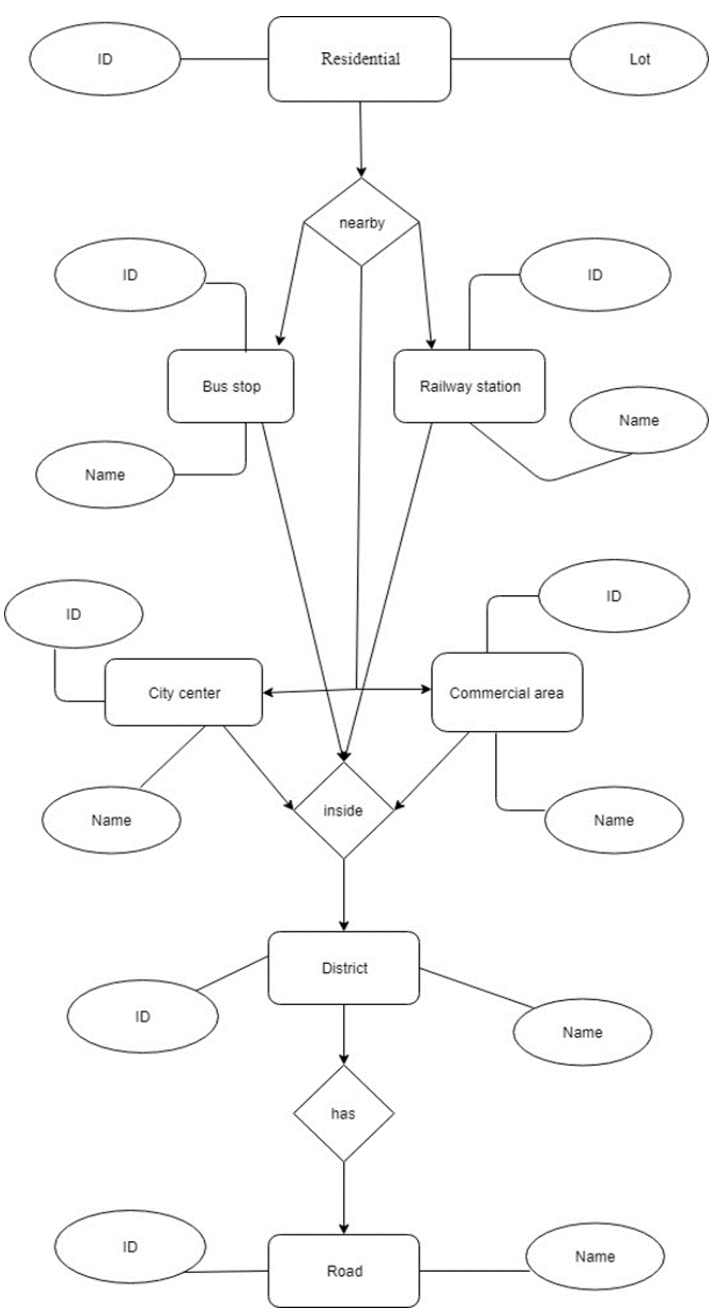

Figure 2. Conceptual design

Logical design is a logical table that compromises the conceptual model that has been transformed into a collection of tables. This design displays the data storage in the computer and also the related software that has been used.

Physical design is the final step in database design. This design characterized the data structure and the accessibility of the data to be efficient in managing the data. The design is developed through Database Management System (DBMS). This design depends on the conceptual and logical design because physical design is developed by referring to the previous designs.

Physical design consists of feature dataset and feature class.

Feature dataset and feature class are the data storage in Geodatabase.

The data required for this study are the basemap of the study area which is Selangor district. Next is the location of the affordable housing in Selangor. Location of the public transportations and commercial area are also needed as indicators of sustainability of the affordable housing. 


\begin{tabular}{|c|c|c|c|c|c|}
\hline Entity & Attribute & Explanation & Data Type & Length & Key \\
\hline \multirow[t]{2}{*}{ Residential } & Residential LID & $\begin{array}{l}\text { Residential Identity } \\
\text { Code }\end{array}$ & double & 10 & PK \\
\hline & Residential Lot & Residential Address & string & 100 & \\
\hline \multirow[t]{2}{*}{ Bus stop } & Bus ID & Bus Identity Code & double & 10 & PK \\
\hline & Bus station & Bus Stop Name & string & 50 & \\
\hline \multirow{2}{*}{$\begin{array}{l}\text { Railway } \\
\text { station }\end{array}$} & Railway ID & Railway Identity Code & double & 10 & PK \\
\hline & Railway name & Railway Name & string & 50 & \\
\hline \multirow[t]{2}{*}{ City center } & Cittoas ID & City Identity Code & double & 10 & PK \\
\hline & City name & City Name & string & 50 & \\
\hline \multirow[t]{2}{*}{$\begin{array}{c}\text { Commercial } \\
\text { area }\end{array}$} & Commercial ID & $\begin{array}{l}\text { Commercial Identity } \\
\text { Code }\end{array}$ & double & 10 & PK \\
\hline & Commercial_name & Commercial place & string & 100 & \\
\hline \multirow[t]{2}{*}{ District } & District ID & District Identity Code & double & 10 & PK \\
\hline & District name & District Name & string & 50 & \\
\hline \multirow[t]{2}{*}{ Road } & Road_LD & Road Identity Code & double & 10 & PK \\
\hline & Road_name & Road Name & string & 100 & \\
\hline
\end{tabular}

Table 1. Logical design

The analysis used in this study are sampling analysis and multi criteria analysis (MCA).

Sampling design is a critical part of any study involving modelling and estimation based on data that is sampled from natural resources or other phenomena occurring in the landscape. To design a spatial sampling scheme is mainly to decide the distribution and the size of sample points. For example, the location of the affordable housing will be displayed as points. Traditionally, sample points correspond with an actual feature point on a topographic map. Well-defined or apparent feature points are always the candidates for sample points.

Multi-criteria analysis (MCA) is a technique used to consider many different criteria when making a decision. In this research, MCA will normalize the score of all the affordable housing and determine the average score for the sustainability level. The score will be determined based on the distance of the spatial indicators from the location of the affordable housing area. Spatial MCA is used for decisions with a geographical element, most often in site selection processes where multiple factors need to be considered. Spatial MCA can be used by any decision-maker needing to consider location.

\section{EXPECTED RESULT}

The result of this study will be the map of the sustainability indicators nearby the affordable housing that will be done in this study.

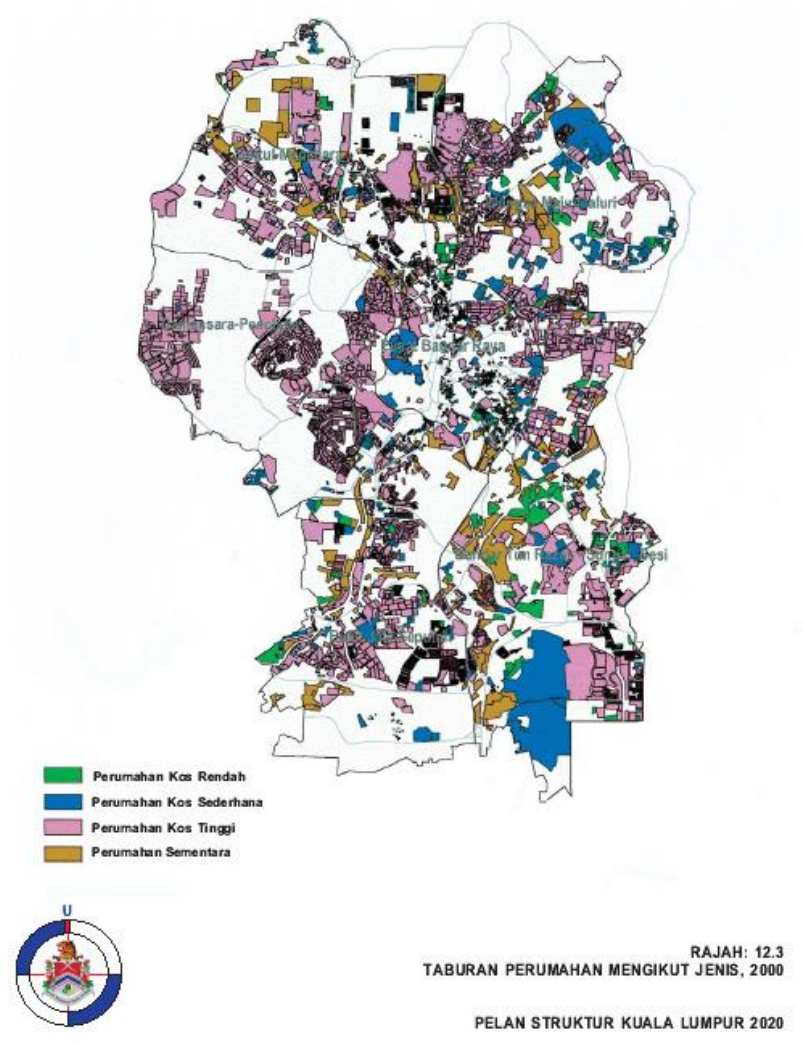

Figure 3. Distribution of affordable housing map

\section{ACKNOWLEDGEMENTS}

Authors would like express our gratitude to Universiti Teknologi Malaysia for funding this project under the Universiti Teknologi Malaysia Grant, GUP (Tier 1), vote number 20H19.

\section{REFERENCES}

Yip, N. M., Mohamad, J., \& Ching, G. H. (2017). Indicators of Sustainable Housing Development (SHD): A Review and Conceptual Framework, 8(9), 306-316.

Sivam, A., \& Karuppannan, S. (2010). The Sustainability of Affordable Housing. The Annual Conference of The Australian Sociological Association (TASA)(Macquarie University, Sydney), (December), 6-9.

PLANMalaysia. (n.d.). PLANMalaysia (Federal Town \&amp; Country Planning Department) Ministry of Urban Wellbeing, Housing \&amp; Local Government MALAYSIAN URBAN RURAL NATIONAL INDICATORS NETWORK FOR SUSTAINABLE DEVELOPMENT (MURNInets 2.0)

Tempatan, K. P. dan K. (2011). Dasar Perumahan Negara, 150. Retrieved from www.kpkt.gov.my

Abdul Kadir, N. B., Wan Sulaiman, W. S., \& Omar, F. (2017). Laporan Indeks Kesejahteraan Keluarga Malaysia 2016. Retrieved from http://www.lppkn.gov.my/Laporan_Indeks_Kesejahteraan_Kelu arga_Malasia_2016.pdf 
Samad, D., Zainon, N., Rahim, F. A. M., \& Lou, E. (2017). Malaysian affordability housing policies revisited. Open House International, $\quad 42(1)$, 44-51. https://doi.org/10.1051/matecconf/20166600010

Woo, R., \& Mangin, J. (2009). What Is Affordable Housing? The Center for Urban Pedagogy 232, NYC Editio(1), 63. Retrieved from http://welcometocup.org/file_columns/0000/0011/cupfullbook.pdf

Bakhtyar, B., Zaharim, A., Sopian, K., Saadatian, O., \& Moghimi, S. (2013). Quality housing in affordable price for Malaysian low income. WSEAS Transactions on Environment and Development, 9(2), 78-91.

Winston, N. (2006). On Indicators of Sustainable Housing in the European Urban Contexts ENHR Conference, Ljubljana 2006 Workshop 13: Housing \& Urban Processes: Towards Sustainable Communities? On indicators of Sustainable Housing in the European Urban Context, (July), 1-15.

Bakhtyar, B., Zaharim, A., Sopian, K., Saadatian, O., \& Abdulateef, J. (2012). Affordable Quality Housing for Urban Low Income Earners in Malaysia. Ssrn, 60-73. https://doi.org/10.2139/ssrn.2184629

Becker, S. (2017). "Affordable" housing. Understanding Housing Policy, 127-154. Retrieved from http://www.jstor.org/stable/j.ctt1t89dc6.13

Wilson, B. W., \& Barton, C. (2018). What is affordable housing?, (07747), 1-29. 